\title{
Effect of N Management on Root Yield and N Uptake of Radishes in Southern China
}

\author{
Wei-Ling Yuan ${ }^{1}$ \\ Institute of Economic Crop, Hubei Academy of Agricultural Science, Wuhan \\ 430070, China
}

Shang-yong Yuan
Vegetable office of Hubei Province, Wuhan 430070, China Xiao-hui Deng, Cai-xia Gan, Lei Cui, and Qing-fang Wang
Institute of Economic Crop, Hubei Academy of Agricultural Science, Wuhan
430070, China

Additional index words. ${ }^{15} \mathrm{~N}, \mathrm{~N}$ management, $\mathrm{N}$ recovery efficiency, $\mathrm{N}$ uptake, radish

Abstract. Efficient nitrogen (N) fertilizer management is crucial for ensuring the maximum economic yield and reducing the risk of environmental pollution. The objective of this study was to determine the effect of $N$ fertilizer management on root yield and $\mathrm{N}$ uptake of radish in southern China by using ${ }^{15} \mathrm{~N}$ isotope tracing. A 2-year field experiment was conducted with three $N$ rates $(0,60$, and $120 \mathrm{~kg} \mathrm{~N} / \mathrm{ha})$ and two different application proportions, viz, A [50\% at basal, $20 \%$ at 15 days after seeding (DAS), 30\% at $30 \mathrm{DAS}]$ and $\mathrm{B}(30 \%$ at basal, $20 \%$ at $15 \mathrm{DAS}, 50 \%$ at $30 \mathrm{DAS})$ for each $\mathrm{N}$ rate, which were expressed as $N_{0}, N_{60 A}, N_{60 B}, N_{120 A}$, and $N_{120 B}$, respectively. The results showed that root yields were significantly increased with $N$ rates increasing from 0 to $120 \mathrm{~kg} \mathrm{~N} / \mathrm{ha}$. The root yields for $\mathrm{N}_{120 \mathrm{~A}}$ and $\mathrm{N}_{120 \mathrm{~B}}$ were $67.60 \mathrm{t} \cdot \mathrm{ha}^{-1}$ and $72.50 \mathrm{t} \cdot \mathrm{ha}^{-1}$ at harvest, $64.07 \%$ and $66.67 \%$ higher than those for the treatments of $\mathrm{N}_{60 \mathrm{~A}}$ and $\mathrm{N}_{60 \mathrm{~B}}$, respectively. Mean radish recovery of $\mathrm{N}$ fertilizer ranged from $25.90 \%$ at $\mathrm{N}_{120 \mathrm{~A}}$ to $32.60 \%$ at $\mathrm{N}_{60 \mathrm{~B}}$, and $\mathrm{N}$ fertilizer residual rate in the soil ranged from $11.50 \%$ at $\mathrm{N}_{120 \mathrm{~A}}$ to $14.90 \%$ at $\mathrm{N}_{60 \mathrm{~B}}$. About $17.50 \%$ to $35.70 \%$ of total uptake of ${ }^{15} \mathrm{~N}$ derived from basal fertilizer was absorbed at seeding stage. However, $61.87 \%$ to $80.18 \%$ of total uptake of ${ }^{15} \mathrm{~N}$ derived from topdressing fertilizer absorbed at root expanding stage. Therefore, appropriate nitrogen application with increasing topdressing nitrogen amount could increase root yield of radish and the nitrogen recovery efficiency. Nitrogen fertilizer application recommended was $120 \mathrm{~kg} \mathrm{~N} / \mathrm{ha}$ with $30 \%$ for basal, $20 \%$ for 15 DAS and $50 \%$ for 30 DAS in this study.

Efficient $\mathrm{N}$ fertilizer management is crucial for ensuring maximum economic production and improving $\mathrm{N}$ recovery efficiency (Guan et al., 2011; Zhang et al., 2013). To increase root yield of the radish, excessive $\mathrm{N}$ fertilizers are applied in the radish production system in southern China. According to Yuan et al. (2014), the optimal $\mathrm{N}$ application rate recommended in radish-producing area was $120 \mathrm{~kg} \mathrm{~N} / \mathrm{ha}$, but rates of 200-300 kg N/ha are common in southern China. Excessive $\mathrm{N}$ fertilizer application can pose potential adverse environmental and health concerns (Deng et al., 2012; Jing et al., 2007) such as groundwater pollution by $\mathrm{NO}_{3}^{-}-\mathrm{N}, \mathrm{NH}_{3}$, and $\mathrm{N}_{2} \mathrm{O}$ volatilization into the atmosphere (Fan et al., 2010; Shi et al., 2010; Wang et al., 2011). In addition, radish is nitrate

Received for publication 12 Feb. 2015. Accepted for publication 11 Mar. 2015.

The work was supported by Hubei foundation of modern agricultural industry technology system and bulk vegetable agricultural technology system in China (CARS-25-A-14).

${ }^{1}$ To whom reprint requests should be addressed; e-mail625041913@qq.com. accumulating vegetable crop. Increasing mineral nitrogen concentration in the soil resulted in increment of nitrates content in radish roots. Effective $\mathrm{N}$ management can reduce the cost of $\mathrm{N}$-fertilizer inputs and minimize nitrate contamination and environmental pollution.

In southern China, farmers usually apply $\mathrm{N}$ fertilizer in two splits (as basal and topdressings) during the radish growth. However, $\mathrm{N}$ utilization efficiency is low all over the main radish producing areas, about $40 \%$ in China (Wang et al., 2013). This may be ascribed to inappropriate $\mathrm{N}$ nutrient managements, including overuse of $\mathrm{N}$ than their required amount and inappropriate time of $\mathrm{N}$ application. Proper $\mathrm{N}$ application timing and rates are critical for meeting plant needs and improving nitrogen utilization efficiency (Zhang et al., 2008). Limaux et al. (1999) reported that the timing of fertilizer $\mathrm{N}$ applications has a significant effect on the uptake of fertilizer $\mathrm{N}$ and the resulting partitioning of added $\mathrm{N}$ between soil and plant. Improving fertilizer $\mathrm{N}$ use efficiency of radish may be not only reduce the negative impacts, but also increase the profitability of radish production and maintain soil fertility.
It has been documented that late application of $\mathrm{N}$ fertilizer could improve the efficiency of $\mathrm{N}$ fertilizer in other crops. Wopereis et al. (2002) reported the effect of optimal $\mathrm{N}$ fertilization rates and timing on dry matter accumulation, grain yield, and $\mathrm{N}$ recovery efficiency in rice. Yang et al. (2013) disclosed that first bloom application was the most important split for $\mathrm{N}$ absorption and yield formation comparatively and allocating more fertilizer $\mathrm{N}$ for late application from preplant application improved the benefit from fertilizer of the cotton. However, few studies have been conducted concerning $\mathrm{N}$ management practices for the radish. What are the difference in plant uptake of fertilizer $\mathrm{N}$ and root yield among the three splits of radish $\mathrm{N}$ application? The objectives of this study were to determine the effects of $\mathrm{N}$ fertilizer management on root yield in radish, and calculate $\mathrm{N}$ recovery efficiencies using ${ }^{15} \mathrm{~N}$-labeled fertilizer methods, as affected by splitting $\mathrm{N}$ application and two different $\mathrm{N}$ rates.

\section{Materials and Methods}

\section{Experimental site}

Field experiments were conducted in the field at the farm of Hubei Academy of Agricultural Science $\left(31^{\circ} 29^{\prime} \mathrm{N}, 114^{\circ} 19 \mathrm{E}^{\prime}\right)$ in 2012 and 2013. The soil of the experimental area was a sandy loam. Soil collected from the upper $20 \mathrm{~cm}$ had a $\mathrm{pH}$ of 5.60 , $31.59 \mathrm{~g} \cdot \mathrm{kg}^{-1}$ organic matter, $0.85 \mathrm{~g} \cdot \mathrm{kg}^{-1}$ total $\mathrm{N}, 11.80 \mathrm{mg} \cdot \mathrm{kg}^{-1} \mathrm{NO}_{3}^{-}-\mathrm{N}, 0.50 \mathrm{mg} \cdot \mathrm{kg}^{-1}$ $\mathrm{NH}_{4}{ }^{+}-\mathrm{N}, 13.10 \mathrm{mg} \cdot \mathrm{kg}^{-1}$ available Olsen-P, and $35.63 \mathrm{mg} \cdot \mathrm{kg}^{-1}$ exchangeable $\mathrm{K}$.

\section{Experimental design and management}

Main plot. The experiments were laid out in randomized complete block design with four replications in 2012 and 2013. There were three $\mathrm{N}$ treatments $(0,60$, and $120 \mathrm{~kg} \mathrm{~N} / \mathrm{ha})$ and two different application proportions, viz, A (50\% at basal, $20 \%$ at $15 \mathrm{~d}$ after seeding (DAS), 30\% at 30 DAS) and B (30\% at basal, $20 \%$ at $15 \mathrm{DAS}, 50 \%$ at 30 DAS) for each $\mathrm{N}$ rate, which were expressed as $\mathrm{N}_{0}, \mathrm{~N}_{60 \mathrm{~A}}, \mathrm{~N}_{60 \mathrm{~B}}, \mathrm{~N}_{120 \mathrm{~A}}$, and $\mathrm{N}_{120 \mathrm{~B}}$, respectively. Additional $60 \mathrm{~kg} \cdot \mathrm{ha}^{-1}$ of phosphorus $\left(\mathrm{P}_{2} \mathrm{O}_{5}\right), 120 \mathrm{~kg} \cdot \mathrm{ha}^{-1}$ of potassium $\left(\mathrm{K}_{2} \mathrm{O}\right)$ and $15 \mathrm{~kg} \cdot \mathrm{ha}^{-1}$ of borate (B) were also applied for the basal fertilizer application. The fertilizers used were calcium superphosphate $(12 \%$ $\left.\mathrm{P}_{2} \mathrm{O}_{5}\right)$, potash chloride $\left(59 \% \mathrm{~K}_{2} \mathrm{O}\right)$ and borate $(10 \%)$. Each plot had an area of $6 \mathrm{~m} \times 6 \mathrm{~m}$. The ridges between adjacent plots were 20 $24 \mathrm{~cm}$ wide at the base and with height of $20 \mathrm{~cm}$, which were covered with metal sheets. The metal was inserted into the soil plough layer to a depth of $30 \mathrm{~cm}$ to contain surface water within the plots and to isolate them hydrologically from adjacent plots.

A double-haploid radish variety, Xuedan 1 (Raphanus sativus L.), a predominant local white radish variety was provided by Hubei Academy of Agricultural Science, Wuhan, China. Radish seeds were sown at $0.50 \mathrm{~cm}$ deep on 8 Sept. 2012 and 10 Sept. 2013. After emergence, plants were thinned $10 \mathrm{~d}$ after 
sowing at a spacing of $20 \mathrm{~cm} \times 30 \mathrm{~cm}$. Root yield was hand-harvested $60 \mathrm{~d}$ after planting. Insects, diseases, and weeds were intensively controlled by using approved pesticides to avoid yield loss.

Microplot experiment. Microplots were designed in the main experimental plots. Each microplot had an area of $3 \mathrm{~m} \times 3 \mathrm{~m}$ with the same plant spacing as the corresponding main plots. To avoid surface runoff and lateral contamination, the microplot was surrounded by $50 \mathrm{~cm}$ metal sheets inserted $30 \mathrm{~cm}$ deep in the soil. In 2012, all the microplots were only applied with labeled ${ }^{15} \mathrm{~N}$ urea (Shanghai Chem-Industry Institute, China). In 2013, each microplot was divided into two parts evenly. Half of the microplots were applied with labeled ${ }^{15} \mathrm{~N}$ urea as basal fertilizer with the same $\mathrm{N}$ rate as the corresponding main plots $1 \mathrm{~d}$ before sowing, and the remaining half of the microplots were applied with labeled ${ }^{15} \mathrm{~N}$ urea as topdressing fertilizer with the same $\mathrm{N}$ rate as the corresponding main plots at $30 \mathrm{DAS}$. In the corresponding main plots, no labeled urea was applied with the same $\mathrm{N}$ rates during the radish growing stages on the same day. To achieve a uniform application of labeled N, fertilizer was applied around the plant $10 \mathrm{~cm}$ apart from the root after being dissolved in the same amount of water to ensure $0.40 \%(\mathrm{w} / \mathrm{w})$ of fertilizer for the highest dosage. The application of $\mathrm{P}$ and $\mathrm{K}$ fertilizers and field management practices in the microplots were the same as the corresponding main plots.

\section{Samplings and analyses}

Soil and plants were sampled from each main and microplot on seeding, expanding, and harvest stages. Soil samples were collected from 0 to $20 \mathrm{~cm}$ depths from all main and microplots. Soil samples were air-dried and ground to pass through a 100-mesh screen for total $\mathrm{N}$ and ${ }^{15} \mathrm{~N}$ isotope analysis according to the method of Martin et al. (1981). Ten representative hills of the plants were sampled and separated into leaf blades and root. The dry weight was determined after oven-drying at $70{ }^{\circ} \mathrm{C}$ to constant weight. Total $\mathrm{N}$ concentrations and ${ }^{15} \mathrm{~N}$ abundance of dry matter and soil were determined after Kjeldahl's micromethod and isotope ratio using a ZHT-03 mass spectrometer (Beijing Analysis Instrument Factory, China). At maturity, 10 hills were taken to determine in each plot to measure the root yield.

\section{Data analysis}

The following percentage of fertilizer $\mathrm{N}$ parameters was calculated for each treatment (Pan et al., 2012; Song et al., 2014):

Nitrogen derived from fertilizer (Ndff) in plant ( $\mathrm{kg} \mathrm{N} / \mathrm{ha}$ ) as the ratio of $\mathrm{N}$ uptake by plant to ${ }^{15} \mathrm{~N}$ atom $\%$ excess in plant to ${ }^{15} \mathrm{~N}$ atom $\%$ excess in fertilizer

Nitrogen derived from soil (Ndfs) in plant $(\mathrm{kg} \mathrm{N} / \mathrm{ha})$ as the difference of total $\mathrm{N}$ uptake by plant and Ndff

Fertilizer $\mathrm{N}$ recovery $(\%)$ as the percentage of Ndff to $\mathrm{N}$ rate
Nitrogen residual rate in the soil as the percentage of $\mathrm{N}$ residual in the soil after harvesting crops to $\mathrm{N}$ rate

Total ${ }^{15} \mathrm{~N}$ accumulation in plant as the sum of total ${ }^{15} \mathrm{~N}$ accumulation in leaf and total

${ }^{15} \mathrm{~N}$ accumulation in root

Data were analyzed following analysis of variance (ANOVA) (SAS Institute, 2003) and mean comparison between treatments was performed based on the least significant difference test at $P=0.05$ level.

\section{Results}

Root yield of radish was significantly increased with increasing the $\mathrm{N}$ rates in 2012 and 2013 (Table 1). The highest yield was recorded for $\mathrm{N}_{120 \mathrm{~B}}$ in 2012, while the lowest one was found under $\mathrm{N}_{0}$ in 2013. Root yield of $\mathrm{N}_{120 \mathrm{~B}}$ treatment was significantly higher than that of $\mathrm{N}_{120 \mathrm{~A}}$ treatment, while no significant difference was observed between $\mathrm{N}_{60 \mathrm{~A}}$ and $\mathrm{N}_{60 \mathrm{~B}}$ in both years. There was significant difference in root length among different $\mathrm{N}$ rates. In 2012, the highest root length was $28.94 \mathrm{~cm}$ under $\mathrm{N}_{120 \mathrm{~B}}$, and the lowest one was $14.05 \mathrm{~cm}$ under $\mathrm{N}_{0}$. Root length generally increased with the applied $\mathrm{N}$ rates. Similarly, the same trend was found for root length in 2013. Apparent difference was found in root diameter and root dry weight between $\mathrm{N}_{120 \mathrm{~A}}$ and $\mathrm{N}_{120 \mathrm{~B}}$. Leaf and root dry weights generally increased as total $\mathrm{N}$ rates increased in both years. However, there was no significant difference in root length and root diameter under $\mathrm{N}_{60 \mathrm{~A}}$ and $\mathrm{N}_{60 \mathrm{~B}}$.
Total $\mathrm{N}$ accumulation by radish plant and the amount of Ndff and soil are presented in Table 2. There was remarkable difference in total $\mathrm{N}$ accumulation among $\mathrm{N}$ application rates. The highest total $\mathrm{N}$ accumulation of $645.20 \mathrm{~kg} \cdot \mathrm{ha}^{-1}$ was recorded under $\mathrm{N}_{120 \mathrm{~B}}$, and the lowest of $104.4 \mathrm{~kg} \cdot \mathrm{ha}^{-1}$ under $\mathrm{N}_{0}$. No apparent difference was found for the different splitting of $\mathrm{N}$ application at the same $\mathrm{N}$ rate. However, significant difference was found for Ndff in plant at harvest in 2012 . The highest $\mathrm{N}$ recovery of labeled fertilizer was $269.70 \mathrm{~kg} \cdot \mathrm{ha}^{-1}$ recorded under $\mathrm{N}_{120 \mathrm{~B}}$, whereas the lowest one was 0 . Similar trend was found for Ndfs in plant. The ratios to total nitrogen accumulation were $32.20 \%, 39.20 \%$, $39.10 \%$, and $41.80 \%$ for the treatments of $\mathrm{N}_{60 A}, \mathrm{~N}_{60 \mathrm{~B}}, \mathrm{~N}_{120 A}$, and $\mathrm{N}_{120 \mathrm{~B}}$, respectively. There was an opposite trend in the percentage of soil $\mathrm{N}$ contribution to total plant $\mathrm{N}$. The highest percentage of Ndfs was observed un$\operatorname{der} \mathrm{N}_{60 \mathrm{~A}}$, while the lowest for $\mathrm{N}_{120 \mathrm{~B}}$, which were $67.80 \%$ and $58.20 \%$, respectively.

Basal and topdressing fertilizer are two important fertilizer sources for the growth of radish. Total ${ }^{15} \mathrm{~N}$ accumulation and its distribution to different organs derived from basal fertilizer ${ }^{15} \mathrm{~N}$ application at the seeding, root expanding, and harvest stages in 2013 are presented in Table 3. Total nitrogen accumulation amounts derived from basal fertilizer ${ }^{15} \mathrm{~N}$, under $\mathrm{N}_{120}$, were significantly higher than those of $\mathrm{N}_{60}$ at seeding, which were 2.70 and $5.60 \mathrm{~kg} \mathrm{~N} / \mathrm{ha}$, respectively. Most of ${ }^{15} \mathrm{~N}$ uptake by radish was allocated in the leaves, and total ${ }^{15} \mathrm{~N}$ accumulation from basal fertilizer ${ }^{15} \mathrm{~N}$ in the leaves was increased with the

Table 1. Root yield, root length, root diameter, leaf dry weight, and root dry weight influenced by nitrogen application in both years.

\begin{tabular}{|c|c|c|c|c|c|}
\hline Treatments & $\mathrm{N}_{0}(\mathrm{CK})$ & $\mathrm{N}_{60 \mathrm{~A}}$ & $\mathrm{~N}_{60 \mathrm{~B}}$ & $\mathrm{~N}_{120 \mathrm{~A}}$ & $\mathrm{~N}_{120 \mathrm{~B}}$ \\
\hline \multicolumn{6}{|l|}{2012} \\
\hline Root yield (t.ha ${ }^{-1}$ ) & $22.70 \mathrm{~d}$ & $41.20 \mathrm{c}$ & $43.50 \mathrm{c}$ & $67.60 \mathrm{~b}$ & $72.50 \mathrm{a}$ \\
\hline Root length $(\mathrm{cm})$ & $14.05 \mathrm{c}$ & $23.75 \mathrm{~b}$ & $24.56 \mathrm{ab}$ & $27.40 \mathrm{a}$ & $28.94 \mathrm{a}$ \\
\hline Root diameter $(\mathrm{cm})$ & $6.05 \mathrm{a}$ & $6.49 \mathrm{a}$ & $6.56 \mathrm{a}$ & $6.72 \mathrm{~b}$ & $6.94 \mathrm{a}$ \\
\hline Leaf dry weight (g/hill) & $6.33 \mathrm{c}$ & $7.12 \mathrm{~b}$ & $7.54 \mathrm{~b}$ & $8.36 \mathrm{a}$ & $8.59 \mathrm{a}$ \\
\hline Root dry weight (g/hill) & $4.47 \mathrm{c}$ & $8.12 \mathrm{~b}$ & $8.57 \mathrm{~b}$ & $12.31 \mathrm{~b}$ & $14.28 \mathrm{a}$ \\
\hline \multicolumn{6}{|l|}{2013} \\
\hline Root yield (t.ha- $\left.{ }^{-1}\right)$ & $22.10 \mathrm{~d}$ & $39.60 \mathrm{c}$ & $41.10 \mathrm{c}$ & $62.90 \mathrm{~b}$ & $70.20 \mathrm{a}$ \\
\hline Root length (cm) & $14.97 \mathrm{c}$ & $23.69 \mathrm{~b}$ & $24.38 \mathrm{ab}$ & $27.15 \mathrm{a}$ & $27.59 \mathrm{a}$ \\
\hline Root diameter $(\mathrm{cm})$ & $6.34 \mathrm{a}$ & $6.37 \mathrm{a}$ & $6.62 \mathrm{a}$ & $6.75 \mathrm{~b}$ & $6.93 \mathrm{a}$ \\
\hline Leaf dry weight (g/hill) & $6.31 \mathrm{c}$ & $7.08 \mathrm{~b}$ & $7.24 \mathrm{~b}$ & $8.42 \mathrm{a}$ & $8.61 \mathrm{a}$ \\
\hline Root dry weight (g/hill) & $4.35 \mathrm{c}$ & $8.02 \mathrm{~b}$ & $8.49 \mathrm{~b}$ & $13.56 \mathrm{~b}$ & $14.59 \mathrm{a}$ \\
\hline
\end{tabular}

Within a row for each parameter, means followed by different letters are significantly different at $P=0.05$ level according to least significant difference test.

Table 2. Nitrogen concentration of dry matter in plant, total nitrogen accumulation (TNA), the amount of nitrogen derived from fertilizer (Ndff) and soil (Ndfs) and the ratio to TNA at harvest in 2012.

\begin{tabular}{|c|c|c|c|c|c|c|}
\hline \multirow[b]{2}{*}{ Treatment } & \multirow[b]{2}{*}{$\begin{array}{c}\mathrm{N} \text { concn in } \\
\text { plant }\left(\mathrm{mg} \cdot \mathrm{g}^{-1}\right)\end{array}$} & \multirow[b]{2}{*}{$\begin{array}{c}\text { TNA } \\
\left(\mathrm{kg} \cdot \mathrm{ha}^{-1}\right)\end{array}$} & \multicolumn{2}{|c|}{ Ndff } & \multicolumn{2}{|c|}{ Ndfs } \\
\hline & & & $\begin{array}{l}\text { Amount } \\
\left(\mathrm{kg} \cdot \mathrm{ha}^{-1}\right)\end{array}$ & $\begin{array}{l}\text { Ratio to } \\
\text { TNA (\%) }\end{array}$ & $\begin{array}{l}\text { Amount } \\
\left(\mathrm{kg} \cdot \mathrm{ha}^{-1}\right)\end{array}$ & $\begin{array}{l}\text { Ratio to } \\
\text { TNA (\%) }\end{array}$ \\
\hline $\mathrm{N}_{0}$ & $4.60 \mathrm{~b}$ & $104.40 \mathrm{c}$ & 0 & 0 & $104.40 \mathrm{c}$ & 100.00 \\
\hline $\mathrm{N}_{60 \mathrm{~A}}$ & $7.80 \mathrm{a}$ & $321.40 \mathrm{~b}$ & $103.50 \mathrm{~d}$ & 32.20 & $217.90 \mathrm{~b}$ & 67.80 \\
\hline $\mathrm{N}_{60 \mathrm{~B}}$ & $7.60 \mathrm{a}$ & $330.60 \mathrm{~b}$ & $129.60 \mathrm{c}$ & 39.20 & $201.00 \mathrm{~b}$ & 60.80 \\
\hline $\mathrm{N}_{120 \mathrm{~A}}$ & $8.50 \mathrm{a}$ & $574.60 \mathrm{a}$ & $224.70 \mathrm{~b}$ & 39.10 & $349.90 \mathrm{a}$ & 60.90 \\
\hline $\mathrm{N}_{120 \mathrm{~B}}$ & $8.90 \mathrm{a}$ & $645.20 \mathrm{a}$ & $269.70 \mathrm{a}$ & 41.80 & $375.50 \mathrm{a}$ & 58.20 \\
\hline
\end{tabular}

Within a row for each parameter, means followed by different letters are significantly different at $P=0.05$ level according to least significant difference test. 
amount of $\mathrm{N}$ application. Uptake of ${ }^{15} \mathrm{~N}$ at seeding under $\mathrm{N}_{60 \mathrm{~A}}$ and $\mathrm{N}_{120 \mathrm{~A}}$ was significantly higher than those of $\mathrm{N}_{60 \mathrm{~B}}$ and $\mathrm{N}_{120 \mathrm{~B}}$, respectively. The same trend was found for the leaves at the root expanding stage. However, there was opposite trend in the uptake of ${ }^{15} \mathrm{~N}$ derived from basal fertilizer at harvest, when the amount taken from 50\% application of the total fertilizer as basal was less than that taken from $30 \%$ of total fertilizer as basal. Smaller amounts of ${ }^{15} \mathrm{~N}$ derived from basal fertilizer were absorbed by radish at seeding stages, which were in the range of $17.50 \%$ to $35.70 \%$. However, $21.60 \%$ to $27.60 \%$ and $42.30 \%$ to $57.30 \%$ of ${ }^{15} \mathrm{~N}$ derived from basal fertilizer was absorbed at root expanding stages and harvest, respectively.

Increasing $\mathrm{N}$ application significantly enhanced ${ }^{15} \mathrm{~N}$ uptake derived from topdressing of fertilizer at 30 DAS at the root expanding stage (Table 4). Uptake of ${ }^{15} \mathrm{~N}$ under $\mathrm{N}_{120}$ of $29.10 \mathrm{~kg} \cdot \mathrm{ha}^{-1}$ was significantly higher than that of $19.30 \mathrm{~kg}{ }^{15} \mathrm{~N} / \mathrm{ha}{ }^{15} \mathrm{~N}$ under $\mathrm{N}_{60}$ at root expanding stage. Most of ${ }^{15} \mathrm{~N}$ uptake was allocated in the leaves, ranging from 10.20 to $16.90 \mathrm{~kg} \cdot \mathrm{ha}^{-1}$. The amounts derived from topdressing ${ }^{15} \mathrm{~N}$ fertilizer under $\mathrm{N}_{120}$ treatment were higher than those of $\mathrm{N}_{60}$ treatment at harvest, which was 17.70 and $8.50 \mathrm{~kg}{ }^{15} \mathrm{~N} / \mathrm{ha}$, respectively. There was $61.87 \%$ to $80.18 \%$ of total uptake of ${ }^{15} \mathrm{~N}$ derived from topdressing fertilizer absorbed at root expanding stage.

The amount of absorption, residual in the soil, and the loss of labeled nitrogen fertilizer in the radish plant-soil system are presented in Table 5. The uptake of ${ }^{15} \mathrm{~N}$ fertilizer was significantly increased with $\mathrm{N}$ applied rates, ranging from 18.30 to $33.70 \mathrm{~kg} \cdot \mathrm{ha}^{-1}$. The same trend was observed for the residual amount of ${ }^{15} \mathrm{~N}$ in the soil. Nitrogen recovery efficiency was significantly decreased with $\mathrm{N}$ application. The highest $\mathrm{N}$ recovery efficiency was found under $\mathrm{N}_{60 \mathrm{~B}}$. The opposite trend was found for the residual rate of ${ }^{15} \mathrm{~N}$ in the soil and the amount of ${ }^{15} \mathrm{~N}$ fertilizer unaccounted, which was in the range of $11.50 \%$ to $14.90 \%$ and $52.50 \%$ to $62.60 \%$, respectively.

\section{Discussion}

Nitrogen fertilizer management practices had significant effects on the root yield and its growth in radish. Delaying $\mathrm{N}$ application could apparently increase the root yield. The reason for higher root yield at $\mathrm{N}_{120 \mathrm{~B}}$ was the increase in root length and root diameter at harvest (Table 1). Our results coincided with the findings of Yuan et al. (2014), who reported that increase of $\mathrm{N}$ application could enhance the root yield. The highest growth of plant in radish was recorded at the highest $\mathrm{N}$ rates (Srinivas and Naik, 1990). Liao et al. (2009) revealed there were significantly positive and linear relationships between total $\mathrm{N}$ uptake and the fresh weight and dry weight of radish. Similar findings were also reported by Zhang et al.
(2013) and Pan et al. (2012) for field grown rice, who found crop yield was affected not only by the rate but also by the time of $\mathrm{N}$ application.

This study found that higher $\mathrm{N}$ application rate could increase total $\mathrm{N}$ accumulation, and delaying nitrogen application increased total $\mathrm{N}$ accumulation and $\mathrm{N}$ recovery efficiency at the same $\mathrm{N}$ rate. Smaller amounts of ${ }^{15} \mathrm{~N}$ derived from basal fertilizer were absorbed by radish at seeding stages, ranging from $17.50 \%$ to $35.70 \%$. However, $61.87 \%$ to $80.18 \%$ of total uptake of ${ }^{15} \mathrm{~N}$ derived from topdressing fertilizer absorbed at the root expanding stage. Similar trend was proved in other field crops that about $20 \%$ of total uptake of ${ }^{15} \mathrm{~N}$ derived from basal fertilizer was absorbed by rice at the midtillering stage; however, $80 \%$ of ${ }^{15} \mathrm{~N}$ uptake derived from topdressing fertilizer was taken up at the heading stage (Pan et al., 2012). The poor $\mathrm{N}$ recovery efficiency of more fertilizer application at the early growing stage was maybe due to the roots of radish less developed, which can hardly take up more $\mathrm{N}$ applied at seeding stage. In addition, in early growing stage, more $\mathrm{N}$ losses by ammonia volatilization and leaching and a large amount of $\mathrm{N}$ applied unincorporated by the soil microorganisms before available to plants must be taken into account (Li et al., 2008; Lin et al., 2007). The higher efficiency of high $\mathrm{N}$ applications shown in Table 5 may be due to greater concentration

Table 3. Total ${ }^{15} \mathrm{~N}$ accumulation $\left(\mathrm{T}^{15} \mathrm{NA}\right)$ and its distribution to different organs derived from basal fertilizer ${ }^{15} \mathrm{~N}$ application at seeding, root expanding and harvest stages in 2013.

\begin{tabular}{|c|c|c|c|c|c|c|c|c|c|}
\hline \multirow[b]{2}{*}{ Treatment } & \multicolumn{3}{|c|}{ Seeding } & \multicolumn{3}{|c|}{ Root expanding } & \multicolumn{3}{|c|}{ Harvest } \\
\hline & $\begin{array}{c}\mathrm{T}^{15} \mathrm{NA} \\
\left(\mathrm{kg} \cdot \mathrm{ha}^{-1}\right)\end{array}$ & $\begin{array}{c}\mathrm{T}^{15} \mathrm{NA} \text { in leaf } \\
\left(\mathrm{kg} \cdot \mathrm{ha}^{-1}\right)\end{array}$ & $\begin{array}{c}\mathrm{T}^{15} \mathrm{NA} \text { in root } \\
\left(\mathrm{kg} \cdot \mathrm{ha}^{-1}\right)\end{array}$ & $\begin{array}{c}\mathrm{T}^{15} \mathrm{NA} \\
\left(\mathrm{kg} \cdot \mathrm{ha}^{-1}\right)\end{array}$ & $\begin{array}{c}\mathrm{T}^{15} \mathrm{NA} \text { in leaf } \\
\left(\mathrm{kg} \cdot \mathrm{ha}^{-1}\right)\end{array}$ & $\begin{array}{c}\mathrm{T}^{15} \mathrm{NA} \text { in root } \\
\left(\mathrm{kg} \cdot \mathrm{ha}^{-1}\right)\end{array}$ & $\begin{array}{c}\mathrm{T}^{15} \mathrm{NA} \\
\left(\mathrm{kg} \cdot \mathrm{ha}^{-1}\right)\end{array}$ & $\begin{array}{c}\mathrm{T}^{15} \mathrm{NA} \text { in leaf } \\
\left(\mathrm{kg} \cdot \mathrm{ha}^{-1}\right)\end{array}$ & $\begin{array}{c}\mathrm{T}^{15} \mathrm{NA} \text { in root } \\
\left(\mathrm{kg} \cdot \mathrm{ha}^{-1}\right)\end{array}$ \\
\hline$\overline{\mathrm{N}}_{0}$ & - & - & - & - & - & - & - & - & - \\
\hline $\mathrm{N}_{60 \mathrm{~B}}$ & 3.60 & 1.20 & 2.40 & 2.40 & 1.60 & 0.80 & 5.10 & 2.80 & 2.30 \\
\hline $\mathrm{N}_{120 \mathrm{~A}}$ & 4.70 & 2.30 & 2.40 & 4.80 & 2.80 & 1.20 & 7.90 & 3.70 & 4.20 \\
\hline $\mathrm{N}_{120 \mathrm{~B}}$ & 6.50 & 2.80 & 3.70 & 4.00 & 2.60 & 1.40 & 7.70 & 4.50 & 3.20 \\
\hline
\end{tabular}

$-=$ No data.

Table 4. Total ${ }^{15} \mathrm{~N}$ accumulation $\left(\mathrm{T}^{15} \mathrm{NA}\right.$ ) and its distribution to different organs derived from topdressing ${ }^{15} \mathrm{~N}$ fertilizer application at expanding and harvest in 2013.

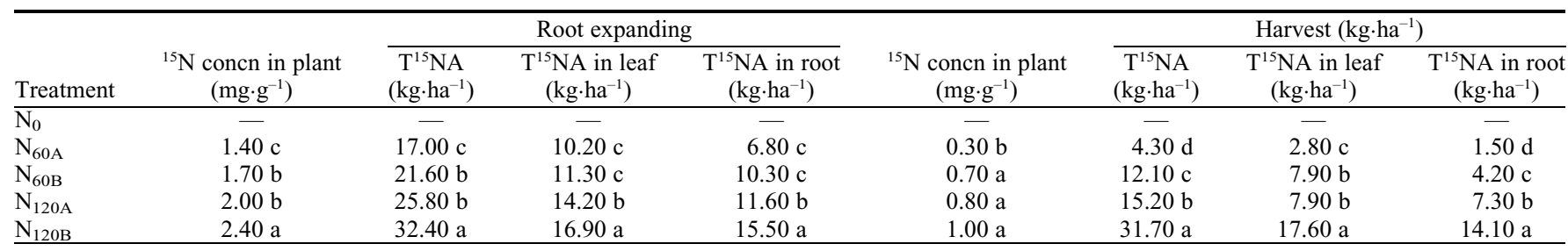

Within a row for each parameter, means followed by different letters are significantly different at $P=0.05$ level according to least significant difference test. $-=$ No data.

Table 5. The amount of absorption, residual in the soil and the loss of labeled nitrogen fertilization in the radish plant-soil system in 2013.

\begin{tabular}{|c|c|c|c|c|c|c|}
\hline Treatment & $\begin{array}{l}\text { Amount of absorption } \\
\left(\mathrm{kg} \cdot \mathrm{ha}^{-1}\right)\end{array}$ & $\begin{array}{l}\text { Nitrogen recovery } \\
\text { efficiency }(\%)\end{array}$ & $\begin{array}{l}\text { Residual amount in the } \\
\text { soil }\left(\mathrm{kg} \cdot \mathrm{ha}^{-1}\right)\end{array}$ & $\begin{array}{l}\text { Residual } \\
\text { rate }(\%)\end{array}$ & $\begin{array}{l}\text { Amount of loss } \\
\left(\mathrm{kg} \cdot \mathrm{ha}^{-1}\right)\end{array}$ & $\begin{array}{l}\text { Unaccounted } \\
\text { rate }(\%)\end{array}$ \\
\hline $\mathrm{N}_{60 \mathrm{~A}}$ & $18.30 \mathrm{~b}$ & $30.50 \mathrm{a}$ & $8.40 \mathrm{~d}$ & $14.00 \mathrm{a}$ & $33.30 \mathrm{~b}$ & $55.50 \mathrm{~b}$ \\
\hline $\mathrm{N}_{60 \mathrm{~B}}$ & $19.60 \mathrm{~b}$ & $32.60 \mathrm{a}$ & $9.00 \mathrm{c}$ & $14.90 \mathrm{a}$ & $31.40 \mathrm{~b}$ & $52.50 \mathrm{c}$ \\
\hline $\mathrm{N}_{120 \mathrm{~A}}$ & $31.10 \mathrm{a}$ & $25.90 \mathrm{c}$ & $13.90 \mathrm{~b}$ & $11.50 \mathrm{c}$ & $75.00 \mathrm{a}$ & $62.60 \mathrm{a}$ \\
\hline $\mathrm{N}_{120 \mathrm{~B}}$ & $33.70 \mathrm{a}$ & $28.10 \mathrm{~b}$ & $16.90 \mathrm{a}$ & $14.10 \mathrm{~b}$ & $69.40 \mathrm{a}$ & $57.80 \mathrm{~b}$ \\
\hline
\end{tabular}

Within a row for each parameter, means followed by different letters are significantly different at $P=0.05$ level according to least significant difference test. 
of fertilizer in the root area at higher ${ }^{15} \mathrm{~N}$ rates, thus stimulating development of a larger and more effective root system for the recovery of soil $\mathrm{N}$, rather than to the effect of mineralization-immobilization turnover suggested by Strong (1995), due to which losses of labeled $\mathrm{N}$ through immobilization would be proportionately greater at lower ${ }^{15} \mathrm{~N}$ fertilizer rates. Therefore, $\mathrm{N}$ fertilizer utilization efficiency should be improved by applying $\mathrm{N}$ at the right period when the plant requires it the most (Yang et al., 2013).

The total $\mathrm{N}$ uptake is closed related to the amount of plant $\mathrm{N}$ derived from the soil. Limaux et al. (1999) reported that the timing of fertilizer $\mathrm{N}$ applications has a significant effect on the uptake of fertilizer $\mathrm{N}$ by the crop and the resulting partitioning of added $\mathrm{N}$ between soil and plant. This study found that the $\mathrm{N}$ uptake from indigenous soil $\mathrm{N}$ was decreased with the $\mathrm{N}$ applied rate. The amounts derived from soil fertilizer $\mathrm{N}$ uptake under $\mathrm{N}_{120}$ treatment were lower than those of $\mathrm{N}_{60}$ treatment. The contribution of unlabelled $\mathrm{N}$ ranged between $58.20 \%$ and $67.80 \%$, while only $32.20 \%$ to $41.80 \%$ was derived from the ${ }^{15} \mathrm{~N}$-labeled fertilizer (Table 2). This result showed that most of total $\mathrm{N}$ uptake by radish was derived from indigenous soil $\mathrm{N}$.

Increasing the synchronization between crop $\mathrm{N}$ demand and the available $\mathrm{N}$ supply to decrease the $\mathrm{N}$ residual rate in the soil is important for efficient $\mathrm{N}$ fertilizer management. In this study, higher $\mathrm{N}$ fertilizer rates increased the amount of residual $\mathrm{N}$ in the soil, and decreased the percentage of ${ }^{15} \mathrm{~N}$ fertilizer residual in the soil (Table 5). This showed that the fertilizers contributed little to the total $\mathrm{N}$ absorbed by the plants and the most was derived from indigenous soil N. The amounts of unaccounted nitrogen might be lost mainly through leaching, denitrification and ammonia volatilization. The results showed that the amount of unaccounted ${ }^{15} \mathrm{~N}$ at harvest derived from $30 \%$ of total fertilizer as basal dose was lower than that taken from $50 \%$ application of total fertilizer as basal. Splitting N application of 50\% total fertilizer as basal might have stronger abilities to absorb the nutrients from water and soil, and reduced $\mathrm{N}$ loss and resulted in higher $\mathrm{N}$ uptake by radish. Therefore, based on yield and nitrogen recovery efficiency, it can be concluded that nitrogen fertilizer application recommended was $120 \mathrm{~kg} \mathrm{~N} /$ ha with $30 \%$ for basal, $20 \%$ for 15 DAS and $50 \%$ for 30 DAS in this study.

\section{Conclusion}

Root yields were significantly increased with $\mathrm{N}$ rates increasing from 0 to $120 \mathrm{~kg}$ $\mathrm{N} \cdot \mathrm{ha}^{-1}$. Appropriate nitrogen application with increasing topdressing nitrogen amount could increase root yield of radish and the nitrogen recovery efficiency. Nitrogen fertilizer application recommended was $120 \mathrm{~kg} \mathrm{~N} /$ ha with $30 \%$ for basal, $20 \%$ for 15 DAS and $50 \%$ for 30 DAS in this study. The proper $\mathrm{N}$ application is not only critical for meeting plant needs, but also improving nitrogen utilization efficiency and minimizing environmental pollution.

\section{Literature Cited}

Deng, M.H., X.J. Shi, Y.H. Tian, B. Yin, S.L. Zhang, Z.L. Zhu, and S.D. Kimura. 2012. Optimizing nitrogen fertilizer application for rice production in the Taihu Lake region, China. Pedosphere 22(1):48-57.

Fan, J.B., Y.L. Zhang, D. Turner, Y.H. Duan, D.S. Wang, and Q.R. Shen. 2010. Root physiological and morphological characteristics of two rice cultivars with different nitrogen-use efficiency. Pedosphere 20(4):446-455.

Guan, G., S.X. Tu, J.C. Yang, and L. Yang. 2011. A field study on effects of nitrogen fertilization modes on nutrient uptake, crop yield and soil biological properties in rice wheat rotation system. Agr. Sci. China 10:1254-1261

Jing, Q., B.A.M. Bouman, H. Hengsdijk, H.V Keulen, and W.X. Cao. 2007. Exploring options to combine high yields with high nitrogen use efficiencies in irrigated rice in China. Eur. J. Agron. 26:166-177.

Li, H., X.Q. Liang, Y.X. Chen, G.M. Tian, and Z.J. Zhang. 2008. Ammonia volatilization from urea in rice fields with zero-drainage water management. Agr. Water Mgt. 95:887-894.

Liao, Y.L., X.M. Rong, S.X. Zheng, Q. Liu, M.R Fan, J.W. Peng, and G.X. Xie. 2009. Influences of nitrogen fertilizer application rates on radish yield, nutrition quality, and nitrogen recovery efficiency. Front. Agr. China 3(2):122-129.

Limaux, F., S. Recous, J.M. Meynard, and A. Guckert. 1999. Relationship between rate of crop growth at date of fertilizer $\mathrm{N}$ application and fate of fertilizer $\mathrm{N}$ applied to winter wheat. Plant Soil 214:49-59.

Lin, D.X., X.H. Fan, F. Hu, H.T. Zhao, and J.F. Luo. 2007. Ammonia volatilization and nitrogen utilization efficiency in response to urea application in rice fields of the Taihu Lake Region, China. Pedosphere 17:639-645.

Martin, F., B. Maudinas, M. Chemardin, and P. Gadal. 1981. Preparation of submicrogram nitrogen samples for isotope analysis by GS1 emission spectrometer. Intl. J. Appl. Radiat. Is $32: 215-217$

Pan, S.G., S.Q. Huang, J. Zhai, J.P. Wang, C.G. Cao, M.L. Cai, M. Zhan, and X.R. Tang. 2012 Effects of $\mathrm{N}$ management on yield and $\mathrm{N}$ uptake of rice in central China. J. Integrative Agr. 11(2): 1993-2000.

SAS Institute. 2003. SAS Version 9.1.2, 20022003. SAS Institute, Cary, NC.

Shi, S.W., Y. Li, Y.T. Liu, Y.F. Wan, Q.Z. Gao, and Z.X. Zhang. 2010. $\mathrm{CH}_{4}$ and $\mathrm{N}_{2} \mathrm{O}$ emission from rice field and mitigation options based on field measurements in China: An integration analysis. Scientia Agr. Sinica. 43:2923-2936 (in Chinese).

Song, G., X. Zhao, S.Q. Wang, and G.X. Xing. 2014. Nitrogen isotopic fractionation related to nitrification capacity in agricultural soils. Pedosphere 24(2):186-195.

Srinivas, K. and L.B. Naik. 1990. Growth and yield of radish (Raphanus sativus L.) in relation to nitrogen and potash fertilization. Indian J. Hort. 47:114-119.

Strong, W.M. 1995. Nitrogen fertilization of upland crops, p. 129-169. In: P.E. Bacon (ed.). Nitrogen fertilization in the environment. Marcel Dekker, NY.

Wang, H.Y., K.L. Hu, B.G. Li, and L. Jin. 2011. Analysis of water and nitrogen use efficiencies and their environmental impact under different water and nitrogen management practices. Scientia Agr. Sinica. 44:2701-2710 (in Chinese).

Wang, Q.F., W.L. Yuan, C.X. Gan, Y.H. Liu, J.W. Zhang, and S.Y. Mei. 2013. Effects of nitrogen application on yield and nitrogen uptake and utilization of radish. J. Anhui Agr. Sci. 41(20):8580-8582.

Wopereis, P.M.M., H. Watanabe, J. Moreira, and M.C.S. Wopereis. 2002. Effect of later nitrogen application on rice yield, grain quality and profitability in the Senegal River valley. Euro. J. Argon 17:191-198.

Yang, G.Z., K.Y. Chu, H.Y. Tang, Y.C. Nie, and X.L. Zhang. 2013. Fertilizer ${ }^{15} \mathrm{~N}$ accumulation, recovery and distribution in cotton plant as affected by $\mathrm{N}$ rate and split. J. Integrative Agr. 12(6):999-1007.

Yuan, W.L., S.Y. Yuan, Q.F. Wang, C.X. Gan, Y.H. Liu, and S.Y. Mei. 2014. Effect of different amount of $\mathrm{N}$-fertilizers on growth, root yield and nitrate content of white radishes in Southern China. J. Food Agr. Environ. 12(1):302-304.

Zhang, J., A.M. Blackmer, P.M. Kyveryga, B.W. Van De Woestyne, and T.M. Blackmer. 2008. Fertilizer-induced advances in corn growth stage and quantitative definitions of nitrogen deficiencies. Pedosphere 18(1):60-68.

Zhang, J.H., J.L. Liu, J.B. Zhang, Y.N. Cheng, and W.P. Wang. 2013. Nitrate-nitrogen dynamics and nitrogen budgets in rice-wheat rotations in Taihu Lake region, China. Pedosphere 23(1):59-69. 